\title{
WANPRESTASI PERUSAHAAN FREIGHT FORWARDER DALAM PENGIRIMAN BARANG MUATAN MELALUI LAUT
}

\section{Elvira Fitra Octaviola}

Universitas Pembangunan Nasional (UPN) Veteran Jawa Timur, Indonesia

Email: elvirafitra@gmail.com

\begin{tabular}{l}
\hline INFO ARTIKEL \\
\hline Diterima \\
3 Juni 2021 \\
Direvisi \\
8 Juni 2021 \\
Disetujui \\
21 Juni 2021 \\
\hline
\end{tabular}

Keywords:

Freight Forwarder, carriage, default.

\begin{abstract}
This research is about the default conducted by freight forwarder company to the sender of goods. This research is based on the Civil Code (KUHPerdata), The Trade Law (KUHD), the Shipping Act, and the Consumer Protection Act. Based on research at PT. IFB Indonesia Surabaya. This type of research uses normative methods with data collection techniques in library studies such as reading various laws and regulations, books, and other science sources related to research, research is also supported by interviews conducted by researchers. Data analysis is a qualitative approach to primary and secondary data. The results of this study can be concluded that the form of default carried out is the goods belonging to the sender of damaged goods when arriving at the destination. The agreement between the sender of the goods and the Freight Forwarder Company still has shortcomings such as the agreement clause does not contain the obligations of freight forwarder, the agreement in The Indonesian language is less easy to understand, some clauses contained in the agreement are less clear, the lack of clause "settlement of problems is preferred to be done in deliberation", and in the awarding of compensation has not been in accordance with the agreement or kuhd. Legal remedies are the awarding of damages which is the responsibility of the Freight Forwarder Company. The legal protections chosen in this case use a non-litigation path in the form of negotiations.
\end{abstract}

\footnotetext{
ABSTRAK

Penelitian ini mengenai wanprestasi yang dilakukan oleh Perusahaan Freight Forwarder terhadap pengirim barang. Penelitian ini berdasarkan Kitab Undang Undang Hukum Perdata (KUHPerdata), Kitab Undang Undang Hukum Dagang (KUHD), Undang-Undang Pelayaran, dan Undang-Undang Perlindungan Konsumen. Berdasarkan penelitian di PT. IFB Indonesia Surabaya.
}

$\begin{array}{ll}\text { How to cite: } & \text { Octaviola, Elvira Fitria (2021) Wanprestasi Perusahaan Freight Forwarder dalam Pengiriman Barang } \\ & \text { Muatan melalui Laut. Jurnal Syntax Admiration 2(6). https://doi.org/10.46799/jsa.v2i6.258 } \\ \text { E-ISSN: } & 2722-5356 \\ \text { Published by: } & \text { Ridwan Institute }\end{array}$


Kata Kunci: freight pengangkutan; wanprestasi
Jenis penelitian ini menggunakan metode normatif dengan teknik pengumpulan data secara studi pustaka seperti melakukan kegiatan membaca berbagai peraturan perundang-undangan, buku, dan sumber ilmu lainnya terkait dengan penelitian, penelitian juga ditunjang dengan adanya wawancara yang dilakukan oleh peneliti. Analisis data yang dilakukan adalah pendekatan kualitatif terhadap data primer dan sekunder. Hasil dari penelitian ini dapat disimpulkan bahwa bentuk dari wanprestasi yang dilakukan yaitu barang muatan milik pengirim barang rusak saat tiba di tempat tujuan. Perjanjian antara pengirim barang dengan Perusahaan Freight Forwarder berbentuk perjanjian tertulis yang jenisnya perjanjian baku. Perjanjian antara pengirim barang dan Perusahaan Freight Forwarder masih memiliki kekurangan seperti klausul perjanjian kurang memuat kewajiban Freight Forwarder, perjanjian dalam bahasa Indonesia kurang mudah untuk dipahami, beberapa klausul yang ada dalam perjanjian kurang jelas, kurang nya klausul "penyelesaian permasalahan diutamakan dilakukan secara musyawarah", dan dalam pemberian ganti rugi belum sesuai dengan perjanjian maupun KUHD. Upaya hukum yang dilakukan adalah Pemberian ganti kerugian yang merupakan tanggung jawab dari Perusahaan Freight Forwarder. Perlindungan hukum yang dipilih dalam kasus ini menggunakan jalur non litigasi yang berbentuk negosiasi.

\section{Pendahuluan}

Indonesia adalah negara yang terkenal dengan negara kepulauan, dimana hal ini sangat menguntungkan Indonesia dalam sektor perhubungan kapal laut karena dikenal sebagai jalur lintas perdagangan dunia. Dikarenakan Indonesia memiliki letak geografis yang strategis, maka hal ini dapat berdampak positif seperti Indonesia akan dengan mudah menjalin relasi dengan bangsa lain termasuk juga relasi dalam sektor ekonomi, selain itu kapal yang digunakan berlalu lalang juga kapal dengan standart yang baik pula. Seperti yang diketahui bahwa pengangkutan dapat dilakukan melalui darat, udara, dan juga laut. Tetapi karena Indonesia ini dikenal sebagai jalur lintas perdagangan dunia maka pengangkutan melalui laut lebih menguntungkan karena barang muatan yang diangkut menggunakan kapal bisa sampai beratus ratus ton namun harganya lebih terjangkau dibanding dengan pengangkutan melalui darat dan juga udara. Dikarenakan pengangkutan melalui laut ini lebih menguntungkan maka banyak pengirim yang lebih memilih mengirimkan barangnya melalui jalur laut. Sehingga pengiriman melalui laut tidak sedikit peminatnya, maka tidak sedikit pula jasa yang menawarkan untuk melakukan pengiriman barang melalui laut. 
Menjalankan suatu pengangkutan barang, peran Jasa Pengurusan Transportasi (Freight Forwarder) tidak dapat dipisahkan dengan kegiatan usaha. Karena berpindahnya suatu barang adalah hal yang akan selalu dilaksanakan dalam perdagangan. Adanya jasa pengurusan transportasi juga memudahkan eksportir, pengirim, dan pemilik barang untuk mengirimkan barangnya. Nantinya pengiriman barang tersebut akan dibantu dikirimkan oleh Freight Forwarder sampai ke tangan penerima dan sebagai imbalannya pengirim barang muatan harus membayarkan upah nya (Saraswati et al., 2017).

Terjadinya suatu prestasi oleh Perusahaan Freight Forwarder untuk mengirimkan barang dari tangan pengirim ke penerima tidak lain bermula dari adanya perjanjian. Peran perjanjian ini sangatlah penting dikarenakan hal yang menyangkut pengiriman melalui laut ini perlu diatur dalam perjanjian. Apabila ada sangketa di kemudian hari maka perjanjian yang telah dibuat di awal dapat membantu menyelesaikan suatu sengketa tersebut. Kasus yang ditemui di salah satu Perusahaan freight forwarder adalah barang muatan yang telah dikirimkan ke tempat tujuan ini sampai dengan keadaan rusak. Dalam hal ini barang muatan yang seharusnya dikirimkan dengan baik oleh Perusahaan Freight Forwarder tetapi sampai di tangan penerima barang tersebut ternyata dalam keadaan rusak saat pengiriman (Farida \& Witasari, 2020).

Usaha Jasa Pengurusan Transportasi (Freight Forwarder) adalah pengangkut meskipun tidak memiliki alat transport sendiri, melainkan bekerja sama dengan berbagai pihak dalam pengangkutan. Jadi tanggung jawab perusahaan Freight Forwarder sama dengan pengangkut. Sehingga menurut pasal 40 ayat (1) Undang Undang Nomor 17 Tahun 2008 tentang Pelayaran bahwa Perusahaan angkutan di perairan wajib untuk bertanggung jawab menjaga keselamatan dan keamanan penumpang dan barang-barang yang diangkut. Selanjutnya menurut ayat (2) pasal 40 Undang Undang Nomor 17 Tahun 2008 tentang Pelayaran bahwa Perusahaan angkutan di perarairan memiliki tanggung jawab terhadap muatan yang ada dalam kapal sesuai jenis dan jumlah barang yang tertera dalam perjanjian (Tjitrawati, 2010).

Menurut pasal 468 KUHD menjelaskan mengenai tanggung jawab pengangkut yaitu perjanjian pengangkutan yang menjanjikan pengangkut agar menjaga barang muatan yang diangkutnya dari saat penerimaan barang sampai dengan penyerahan kepada penerima. Pengangkut harus mengganti kerugian apabila tidak menyerahkan barang sebagian atau seluruhnya atau jika barang yang diangkutnya rusak, kecuali apabila pengangkut dapat membuktikan bahwa tidak diserahkan barang muatan sebagian atau seluruhnya atau kerusakan barang terjadi karena adanya kejadian yang tidak dapat dicegah oleh pengangkut, atau kerusakan akibat dari kesalahan pengirim atau pemilik barang (Pertiwi, 2019).

Hal ini pihak pengirim atau pemilik barang menyerahkan barang muatan kepada Perusahaan Freight Forwarder dalam keadaan baik dan sudah di packing dengan benar. Namun pada saat sampai di tangan penerima yang dimana sudah melewati panjangnya pengiriman (barang ekspor) barang muatan tersebut sebagian ada yang rusak. Hal ini dikarenakan karena pengangkut kurang menjaga barang muatan milik pengirim. 
Sehingga menyebabkan kerugian yang dialami oleh pengirim atau pemilik barang karena rusaknya barang muatan. Maka adanya kerusakan dalam hal ini masuk kedalam salah satu unsur wanprestasi yaitu prestasi yang dilakukan tidak sempurna.

Permasalahan atau sengketa bersifat umum karena tidak dipungkiri bahwa suatu bisnis akan timbul permasalahan atau sengketa dikemudian harinya. Namun proses penyelesaian permasalahan tersebut adalah hal terpenting dalam Perusahaan. Perusahaan yang dapat menyelesaikan permasalahan dengan baik merupakan Perusahaan yang bertanggung jawab dan dapat bersaing oleh perusahaan lain (Sapa, 2017).

\section{Metode Penelitian}

Penelitian yang digunakan oleh penulis adalah penelitian normatif atau yuridisnormatif, yang dilakukan dengan cara pendekatan perundang-undangan, bahan kepustakaan serta penelitian ini dilakukan terhadap keadaan sebenarnya yang terjadi di masyarakat. Penelitian ini menggunakan data primer dan data sekunder. Data primer diperoleh dari hasil kuesioner, wawancara dan data sekunder diperoleh dari bahan hukum primer, bahan hukum sekunder dan bahan hukum tersier.

\section{Hasil dan Pembahasan}

1. Perjanjian Pengiriman Barang Di Perusahaan Freight Forwarder

a. Bentuk Perjanjian antara Perusahaan Freight Forwarder (PT. IFB Indonesia) dengan Pengirim atau Pemilik Barang Muatan.

Perjanjian merupakan suatu wujud dimana satu orang atau lebih berjanji kepada satu orang atau lebih untuk melaksanakan suatu prestasi (Ali, 2016). Apabila telah mencapai sepakat (konsensus) dari dua belah pihak tersebut maka perjanjian sudah terlaksana. Sesuai dengan pasal 1313 KUHPerdata bahwa "Suatu persetujuan adalah suatu perbuatan dimana satu orang atau lebih mengikatkan diri terhadap satu orang atau lebih." Apabila seseorang mengikatkan dirinya kepada orang lain, maka akan timbul hak dan kewajiban yang harus dilaksanakan atau diterima oleh para pihak (Sinaga, 2018).

Bentuk dari perjanjian yang diakui oleh Kitab Undang Undang Hukum Perdata (KUHPerdata) adalah:

1) Perjanjian tertulis

Perjanjian dapat berbentuk perjanjian tertulis. Sebagai wujud dari terlaksananya perjanjian, maka pasti adanya bukti dari timbulnya perjanjian, apabila perjanjian tersebut dilakukan secara tertulis maka akan ada wujud dari janji yang ditulis.

2) Perjanjian lisan

Sedangkan perjanjian lisan merupakan perjanjian yang dilaksanakan secara lisan atau hanya kesepakatan antara para pihak saja. Dalam pengangkutan biasanya perjanjian lisan disertai dengan adanya bukti (contoh: 
karcis apabila menaiki transportasi umum). Kedua perjanjian lisan maupun tertulis ini tetap sama-sama sah dan mengikat para pihaknya.

Dalam kasus ini permasalahan terjadi pada akhir tahun 2020. Dalam perjanjian antara pemilik barang dengan Perusahaan Freight Forwarder (PT. IFB Indonesia) dilakukan dengan perjanjian tertulis. Sesuai dengan perjanjian klausul 2.1 pada syarat dan ketentuan PT. IFB Indonesia yang isinya adalah: "Semua bisnis yang dilakukan Perusahaan ditransaksikan tunduk pada ketentuan ini, yang mana akan dianggap tergabung dalam perjanjian apa pun antara Perusahaan dan Pelanggan." Maka apabila pemilik barang mengirimkan barang di PT. IFB Indonesia maka harus mengikuti syarat dan ketentuan yang telah dibuat oleh PT. IFB Indonesia, begitu juga untuk PT. IFB sebagai pengangkut yang harus tunduk pada syarat dan ketentuan juga.

Suatu perjanjian yang telah disepakati maka akan menimbulkan prestasi antara dua belah pihak. Sesuai dengan pasal 1234 bahwa prestasi dapat berupa memberikan sesuatu (barang), melakukan sesuatu yang berupa jasa, ataupun tidak berbuat apapun. Prestasi yang akan dilakukan oleh Freight Forwarder ini yaitu melakukan sesuatu yang berarti jasa. Prestasi yang harus dilaksanakan oleh pihak Freight Forwarder yaitu mengantarkan barang dari tangan pengirim, sampai dengan ke penerima. Lalu prestasi yang harus dilaksanakan oleh pemilik barang yaitu harus membayarkan upah ke pihak Freight Forwarder.

Perusahaan Freight Forwarder menggunakan perjanjian tertulis. Dalam perjanjian yang berbentuk tertulis ini maka dapat menjamin adanya kepastian hukum atau perjanjian tersebut dapat dipertanggung jawabkan apabila salah satu pihak tidak melakukan kewajibannya atau wanprestasi. Salah satu kelebihan perjanjian yang bentuknya tertulis ini adalah apabila di kemudian hari terjadi wanprestasi, maka untuk melakukan pembuktian lebih mudah daripada perjanjian lisan.

Perjanjian PT. IFB Indonesia dengan client nya berbentuk perjanjian baku. Perjanjian ini berisi aturan-aturan yang mengikat kepada dua belah pihak telah dibuat oleh Perusahaan Freight Forwarder dan pihak kedua hanya menerima perjanjian tersebut. Perjanjian baku memang boleh digunakan dalam kegiatan bisnis, dikarenakan perjanjian ini dapat dilakukan lebih cepat daripada menyusun perjanjian antar dua pihak.

Perkembangan dalam dunia bisnis semakin maju dan pesat, orang-orang yang ada dalam dunia bisnis mencari hal yang instan atau serba cepat, tidak terkecuali dalam bidang pengangkutan. Apabila menggunakan perjanjian baku maka dapat menghemat waktu, biaya, dan tenaga. Namun dibalik mudahnya perjanjian baku, perjanjian baku juga memiliki kekurangan.

Perjanjian baku lahir karena adanya kebutuhan dalam dunia bisnis. Dalam pasal 1338 ayat (1) tidak dijelaskan lebih rinci batasan mengenai perjanjian yang sebaiknya dibuat. Hanya saja dalam pasal tersebut dijelaskan bahwa perjanjian adalah sah bagi para pihak yang membuat dan berlaku sebagai Undang Undang 
untuk para pihaknya. Perjanjian baku diakui dalam hukum di Indonesia. Sesuai dengan penjabaran dari pasal 1338 ayat (1) yaitu:

a. Para pihak bebas untuk membuat jenis perjanjian

b. Dapat dengan bebas mengatur isi perjanjian

c. Bebas untuk mengatur bentuk perjanjian yang nantinya digunakan

Selain itu tiap-tiap orang berhak untuk mengadakan perjanjian dengan orang lain atau badan hukum lain agar terbentuknya perjanjian yang sah asalkan sesuai dengan pasal 1320 KUHPerdata. Mengingat bahwa perjanjian yang disepakati oleh para pihak adalah menjadi Undang-Undang bagi yang membuatnya sesuai dengan pasal 1338 KUHPerdata. Namun perjanjian baku berbeda dengan perjanjian yang umumnya dilakukan. Perjanjian baku ini tidak ada negoisasi yang dilakukan oleh para pihak. Pihak kedua (calon pengirim barang) akan diberikan perjanjian yang telah dibuat oleh pihak pertama (PT. IFB Indonesia) dan harus menyetujui perjanjian tersebut, apabila pihak kedua tidak bersedia menerima perjanjian dan klausula yang telah tercantum dan dibuat oleh pihak pertama maka perjanjian tidak dapat dilanjutkan. Sehingga kedua belah pihak sama-sama belum terikat dan belum terbebani oleh hak dan kewajiban (Wicaksono, 2017).

Dalam hal persetujuan di perjanjian seperti yang ada dalam pasal 1321 bahwa tiap orang yang menyetujui suatu perjanjian tidak lah sah apabila sepakat itu dilakukan karena adanya khilaf atau diperoleh karena paksaan maupun penipuan. Maka dalam menyetujui perjanjian harus dilaksanakan dengan sukarela antara para pihaknya yang tidak didapatkan dari paksaan dan penipuan pihak lain.

Perjanjian antara PT. IFB Indonesia dengan pihak pemilik barang merupakan perjanjian baku, yang menurut penulis perjanjian ini masih memiliki kekurangan, seperti yang diketahui bahwa kewajiban Freight Forwarder adalah mengurus barang dari mulai pemilik barang akan mengirimkan barang dari pelabuhan atau gudang asal sampai dengan ke pelabuhan atau gudang tujuan (penerima) yang juga harus memperhatikan kondisi barang tersebut hingga nantinya sampai ke penerima dengan kondisi baik. Seperti yang tercantum dalam The Hague Rules 1924 article 1 (e) "Carriage of goods covers the period from the time when the goods are loaded on to the time they are discharged from the ship". Klausul mengenai kewajiban ini tidak tercantum dalam perjanjian baku ini. Sehingga ditakutkan jika pihak Freight Forwarder tidak melaksanakan kewajiban tersebut. Meskipun dalam perjanjian dituliskan megenai tanggung jawab Freight Forwarder apabila barang muatan sampai ke tempat tujuan rusak akan diberi ganti rugi oleh PT. IFB Indonesia, namun menurut penulis alangkah lebih baik jika klausul "Pihak Freight Forwarder akan menjaga barang muatan hingga sampai ke tempat tujuan" ini dimasukkan dalam perjanjian. Selain dari hal ini perjanjian yang telah dibuat oleh pihak Freight Forwarder adalah baik yang artinya seimbang, seperti hal nya yang dikatakan oleh Corley dan Shedd yang merupakan sarjana hukum Amerika bahwa perjanjian baku bukannya tidak boleh dilakukan atau ilegal, tetapi harus diteliti keadilan dari suatu perjanjian baku tersebut. 
b. Analisa Perjanjian Pengangkutan yang digunakan oleh Perusahaan Freight Forwarder (PT. IFB Indonesia) dengan Pengirim atau Pemilik Barang.

Perjanjian yang dilakukan oleh pemilik barang dengan Perusahaan Freight Forwarder menurut penulis ada beberapa kekurangan dalam perjanjian seperti:

1) Menurut pasal 4 Undang Undang nomor 8 Tahun 1999 tentang Perlindungan Konsumen dijelaskan mengenai hak-hak yang harus diterima oleh konsumen, salah satunya pasal 4 ayat 1 bahwa "hak atas kenyamanan, keamanan, dan keselamatan dalam mengkonsumsi barang dan jasa". Menurut pasal ini pelaku usaha (PT. IFB Indonesia) harus memenuhi salah satu hak konsumen untuk memberikan keselamatan barang yang diangkutnya hingga sampai tujuan. Selanjutnya menurut pasal 468 KUHD "Perjanjian pengangkutan menjanjikan pengangkut untuk menjaga keselamatan barang yang harus diangkut dari saat penerimaan sampai penyerahannya. Pengangkut harus mengganti kerugian karena tidak menyerahkan seluruh atau sebagian barangnya atau karena ada kerusakan, kecuali bila Ia membuktikan bahwa tidak diserahkan barang itu seluruhnya atau sebagian atau kerusakan itu adalah akibat suatu kejadian yang selayaknya tidak dapat dicegah atau dihindarinya, akibat sifatnya, keadaannya atau suatu cacat barangnya sendiri atau akibat kesalahan pengirim (Rahmayani, 2018). Ia bertanggung jawab atas tindakan orang yang dipekerjakannya, dan terhadap benda yang digunakannya dalam pengangkutan itu”. Menurut pasal 468 KUHD ini perjanjian pengangkutan antara pengangkut dengan pemilik barang muatan mewajibkan pengangkut untuk menjaga barang-barang muatan pemilik hingga sampai pada tempa tujuan. Apabila barang muatan pemilik tidak dapat diserahkan pengangkut atau barang muatan rusak sebagian atau seluruhnya maka pengangkut wajib memberikan ganti rugi, namun apabila kehilangan atau kerusakan terjadi bukan karena pihak pengangkut maka pengangkut dibebaskan untuk melakukan ganti rugi. Dalam kasus ini Freight Forwarder belum dapat memenuhi pasal 4 Undang Undang Perlindungan Konsumen dan pasal 468 KUHD untuk menjaga barang muatan pemilik. Namun dalam Syarat dan Ketentuan PT. IFB Indonesia tidak ditemukan klausul bahwa perusahaan PT. IFB Indonesia harus menjaga barang muatan pemilik sampai dengan tujuan. Sehingga menurut penulis ini salah satu kekurangan dari perjanjian ini karena menjaga barang muatan adalah kewajiban yang harus dipenuhi oleh Freight Forwarder dan merupakan hak yang harus diterima oleh konsumen.

2) Kurang jelasnya klausul “Aturan Den Haag” berarti Konvensi Internasional untuk penyatuan aturan tertentu. Di klausul ini tidak dijelaskan pasal dalam Konvensi Den Haag yang mana yang digunakan dalam penyatuan aturan, karena dalam klausul perjanjian hanya tertulis penyatuan aturan tertentu. Selain itu tidak dijelaskan apakah seluruh atau sebagian pasal saja yang digunakan dalam The Hague Rule. Sehingga hal ini dapat menyebabkan ambigu atau multi interpretasi bagi yang membaca. Dalam perjanjian, baiknya 
menggunakan bahasa yang mudah dipahami agar tidak menjadi perbedaan penafsiran, dan seharusnya dalam perjanjian telah dijelaskan sedemikian rupa di dalam perjanjian itu sendiri untuk memperjelas agar tidak menyebabkan adanya ambigu.

3) Menurut pasal 31 ayat (1) Undang Undang Nomor 24 Tahun 2009 tentang Bendera, Bahasa dan Lambang Negara Serta Lagu Kebangsaan bahwa penggunaan Bahasa Indonesia yang harus digunakan dalam nota kesepahaman ataupun perjanjian yang melibatkan lembaga negara, pemerintah Republik Indonesia, lembaga swasta yang ada di Indonesia, dan perseorangan warga negara Indonesia. Adanya perjanjian bilingual dalam perjanjian pengiriman barang di PT. IFB Indonesia, namun perjanjian yang menggunakan Bahasa Indonesia ini kurang jelas dan tidak menggunakan Bahasa Indonesia yang mudah dipahami. Sebenarnya dalam pengiriman barang pada PT. IFB Indonesia ini hanya di berikan perjanjian yang berbahasa Inggris karena customer PT. IFB lebih banyak yang melakukan ekspor/impor, namun apabila meminta versi dalam bahasa Indonesia maka akan diberi. Sehingga dalam hal ini PT. IFB Indonesia sudah sesuai dengan pasal 31 diatas, namun dapat lebih memperjelas bahasa Indonesia yang digunakan dalam perjanjian.

4) Didalam syarat dan ketentuan klausul 22 hanya tertulis: "Ketentuan ini dan setiap kontrak dengan Perusahaan akan diatur oleh hukum Indonesia. Setiap klaim atau perselisihan harus ditentukan secara eksklusif oleh pengadilan di Indonesia dan tidak ada pengadilan lain." Kurangnya klausula penyelesaian masalah didahulukan melalui musyawarah agar mencapai kesepakatan antar para pihak nya. Seperti fakta yang ada di perusahaan apabila terjadi masalah maka perusahaan akan mengutamakan musyawarah atau alternatif penyelesaian sangketa yang dilakukan diluar pengadilan untuk menyelesaikan sangketa.

5) Perjanjian telah tertulis bahwa: "Jika ada kehilangan, kerusakan, penurunan kualitas, ketidakpatuhan atau kesalahan kepatuhan instruksi, tidak terkirim, salah kirim (selain yang dijelaskan dalam klausul 12.1 dan 12.2, pengiriman tidak sah atau penyesatan atau ke atau sehubungan dengan barang itu timbul dari kelalaian atau kesalahan Perusahaan atau yang timbul dari kelalaian, kesalahan, default yang disengaja atau kesalahan yang disengaja dari karyawan, agen atau subkontraktor Perusahaan, Perusahaan akan bertanggung jawab atas klaim apa pun yang berkaitan dengan insiden tersebut di atas. Namun, tanggung jawab Perusahaan tersebut di atas tidak boleh melebihi total 2 SDR per kilogram berat kotor dari bagian barang yang terkait dengan klaim.” Tetapi faktanya apabila suatu barang rusak, ganti rugi yang diberikan oleh perusahaan tidak sesuai dengan apa yang disebutkan oleh klausul 11 diatas. Mengingat pasal 1338 KUHPerdata bahwa perjanjian bersifat mengikat kepada para pihak nya seperti undang-undang. Sama dengan syarat dan ketentuan PT. IFB Indonesia seharusnya perjanjian yang telah ada ini dilaksanakan seperti 
undang-undang bagi para pihaknya. Selain itu pasal 472 KUHD juga menerangkan mengenai banyak nya ganti kerugian yang harus diberikan oleh pihak pengangkut kepada pemilik barang apabila barang yang diangkutnya rusak. Namun pemberian ganti kerugian PT. IFB Indonesia menurut penulis belum sesuai dan tidak berdasar oleh undang-undang maupun perjanjian (syarat dan ketentuan).

2. Upaya yang dapat dilakukan Ketika Terdapat Barang Muatan yang Rusak dalam Pengiriman Akibat Perusahaan Freight Forwarder

a. Akibat Hukum dari Kelalaian Pihak Perusahaan Freight Forwarder (PT. IFB Indonesia) yang Menyebabkan Kerusakan Barang Muatan.

Segala perbuatan yang dilakukan oleh manusia secara sengaja sehingga menimbulkan hak dan kewajiban merupakan perbuatan hukum, menurut R. Soeroso (2011) dalam (Fathony, 2017). Apabila subyek hukum (orang atau badan hukum) melakukan perjanjian yang dikehendakinya, maka akan timbul hak dan kewajiban antara para pihak. Setelah timbul perbuatan hukum maka timbul akibat hukum dari pihak-pihak yang melakukan perbuatan hukum. Dalam kasus perjanjian pengangkutan ini salah satu pihak yaitu pihak pengangkut memiliki kewajiban untuk mengangkut barang muatan dari pihak pengirim sampai dengan pihak penerima dalam keadaan baik, dan memiliki hak untuk menerima upah. Pihak pemilik barang memiliki kewajiban untuk membayar upah dan memiliki hak untuk menerima barang muatan dengan kondisi baik.

Apabila terjadi kerusakan dalam barang muatan yang telah diangkut oleh pihak pengangkut, maka pihak pemilik barang yang barang muatan nya rusak akibatnya adalah berikut:

a. Mengganti kerugian (pasal 1243 KUHPerdata)

b. Perjanjian antara dua belah pihaknya batal dan pihak yang menyebabkan

kerugian tersebut harus membayar ganti rugi yang diderita (pasal 1267

KUHPerdata)

c. Peralihan resiko suatu barang/benda (pasal 1237 KUHPerdata)

Maka dalam permasalahan wanprestasi ini perjanjian yang mengikat dua belah pihak (Freight Forwarder dengan pemilik barang) ini batal demi hukum dan pihak Freight Forwarder diwajibkan untuk mengganti kerugian. Ganti kerugian adalah sanksi yang timbul sebab adanya wanprestasi. Mengingat bahwa ganti kerugian dilakukan karena adanya ingkar janji yang diperbuat oleh pihak Freight Forwarder.

Pertanggung jawaban pengangkut menurut The Hamburg Rules (1978) tercantum di article 4. "Tanggung jawab pengangkut dalam mengangkut barang muatan didalam aturan ini yaitu pada saat barang akan dikirim di pelabuhan, pada saat pengangkutan, dan di pelabuhan pembongkaran barang."

Didalam case atau permasalahan ini terjadinya kerusakan adalah pada saat barang muatan diterima oleh penerima barang. Sehingga sesuai dengan pasal 82 Peraturan Pemerintah Nomor 20 Tahun 2010 tentang Angkutan diperairan bahwa kegiatan Freight Forwarder salah satunya adalah klaim. Klaim merupakan ganti 
rugi yang harus diberikan oleh pihak Freight Forwarder kepada pihak pemilik barang sebab barang yang diangkut oleh pihak Freight Forwarder mengalami kerusakan.

Selain itu menurut pasal 468 ayat (2) KUHD dijelaskan bahwa "Perjanjian pengangkutan menjanjikan pengangkut untuk menjaga keselamatan barang yang harus diangkut dari saat penerimaan sampai penyerahannya. Pengangkut harus mengganti kerugian karena tidak menyerahkan seluruh atau sebagian barangnya atau karena ada kerusakan, kecuali bila Ia membuktikan bahwa tidak diserahkan barang itu seluruhnya atau sebagian atau kerusakan itu adalah akibat suatu kejadian yang selayaknya tidak dapat dicegah atau dihindarinya, akibat sifatnya, keadaannya atau suatu cacat barangnya sendiri atau akibat kesalahan pengirim. Ia bertanggung jawab atas tindakan orang yang dipekerjakannya, dan terhadap benda yang digunakannya dalam pengangkutan itu"

Tanggung jawab PT. IFB Indonesia yang harus dilakukan adalah menjaga barang muatan dari saat barang muatan diserahkan kepada pihak Freight Forwarder yang nantinya akan dikirim sampai dengan barang tersebut sampai kepada tangan penerima. Kewajiban ini timbul akibat dari kesepakatan para pihak. Apabila PT. IFB Indonesia melakukan kesalahan dan/atau kelalaian maka harus bertanggung jawab karena kesalahan dan/atau kelalaian yang telah dilakukan oleh pegawainya. Kesalahan dan/atau kelalaian tersebut dapat berupa kehilangan, kerusakan, penurunan kualitas, ketidakpatuhan atau kesalahan kepatuhan instruksi, tidak terkirim, salah kirim, pengiriman tidak sah atau penyesatan atau hal lain yang dapat timbul karena kesalahan secara sengaja maupun yang tidak disengaja.

Pemberian ganti rugi yang harus dilakukan oleh PT. IFB ini sesuai dengan Syarat dan Ketentuan yang dimiliki oleh PT. IFB Indonesia, menurut point 11 perjanjian yang berbunyi "Jika ada kehilangan, kerusakan, penurunan kualitas, ketidakpatuhan atau kesalahan kepatuhan instruksi, tidak terkirim, salah kirim (selain yang dijelaskan dalam Klausul 12.1 dan 12.2), pengiriman tidak sah atau penyesatan atau ke atau sehubungan dengan barang itu timbul dari kelalaian atau kesalahan perusahaan atau yang timbul dari kelalaian, kesalahan, default yang disengaja atau kesalahan yang disengaja dari karyawan, agen atau subkontraktor Perusahaan, Perusahaan akan bertanggung jawab atas klaim apa pun yang berkaitan dengan insiden tersebut di atas (Hernoko, 2010). Namun, tanggung jawab Perusahaan tersebut di atas tidak boleh melebihi total 2 SDR per kilogram berat kotor dari bagian barang yang terkait dengan klaim." Point 11 dari perjanjian ini mewajibkan PT. IFB Indonesia melaksanakan kewajibannya untuk melakukan tanggung jawab berupa ganti kerugian kepada pihak yang mengalami kerugian dan besarnya ganti rugi tidak boleh lebih dari 2 Special Drawing Right (SDR) per kilogram berat kotor barang muatan yang di klaim.

Syarat dan Ketentuan tersebut merupakan perjanjian yang telah disepakati oleh para pihak yaitu PT. IFB Indonesia dan juga pengirim barang muatan, 
sehingga sesuai dengan pasal 1338 ayat (1) bahwa perjanjian yang dibuat sendiri adalah sah dan berlaku sebagai Undang Undang untuk para pihak yang membuatnya. Maka PT. IFB Indonesia harus mematuhi aturan dalam Syarat Ketentuan tersebut karena PT. IFB Indonesia adalah pihak yang membuat perjanjian tersebut dan perjanjian tersebut adalah sah (Turagan, 2019).

b. Upaya yang dilakukan oleh Kedua Belah Pihak Pemilik/Pengirim Barang Muatan dan Perusahaan Freight Forwarder (PT. IFB Indonesia) untuk Menyelesaikan Permasalahan Kerusakan Barang Muatan dalam Pengiriman Akibat Perusahaan Freight Forwarder (PT. IFB Indonesia)

Upaya penyelesaian permasalahan yang dilakukaan oleh PT. IFB Indonesia adalah melalui penyelesaian sangketa diluar pengadilan atau sering juga disebut alternatif penyelesaian sangketa. Dalam penyelesaian sangketa yang dilakukan oleh PT. IFB Indonesia diluar pengadilan ini diakui oleh Undang-Undang yang berlaku di Indonesia.

Menurut pasal 45 ayat (2) Undang Undang Nomor 8 Tahun 1999 tentang Perlindungan Konsumen disebutkan bahwa "Penyelesaian sangketa konsumen dapat ditempuh melalui pengadilan atau diluar pengadilan berdasarkan suka rela pihak yang bersangketa"

Selanjutnya penyelesaian sangketa antar PT. IFB Indonesia dengan konsumennya dilakukan diluar pengadilan agar tercapainya besarnya ganti rugi yang harus diberikan oleh Perusahaan yang merugikan konsumennya supaya hal seperti ini tidak terulang kembali sesuai dengan pasal 47 Undang Undang Nomor 8 Tahun 1999 tentang Perlindungan Konsumen.

Aturan mengenai alternatif penyelesaian sangketa ini juga ada dalam pasal 1 angka 10 Undang Undang Nomor 30 Tahun 1999 tentang Arbitrase dan Alternatif Penyelesaian Sangketa, yaitu alternatif peyelesaian sangketa adalah suatu lembaga yang menyelesaikan sangketa para pihak atau menyelesaikan sangketa sesuai yang disepakati oleh para pihaknya, yang penyelesaian sangketa nya dilakukan diluar pengadilan.

Berbagai bentuk penyelesaian sangketa non litigasi yang diakui oleh hukum di Indonesia seperti konsultasi, arbitrase, negosiasi, mediasi, konsiliasi, atau penilaian ahli. Dalam menyelesaikan permaasalahan nya bentuk penyelesaian sangketa tergantung oleh para pihak yang bersangketa. Menurut penelitian wanprestasi perusahaan PT. IFB Indonesia ini, PT. IFB Indonesia dengan pihak pemilik barang memilih untuk menyelesaikan permasalahan secara non litigasi atau diluar pengadilan.

PT. IFB Indonesia dengan pihak pemilik barang memilih untuk menyelesaikan secara musyawarah atau negoisasi untuk menghitung berapa banyak ganti rugi yang harus diberikan oleh PT. IFB Indonesia. Hal mengenai musyawarah dalam perjanjian sepihak PT. IFB Indonesia ini memang tidak tercantumkan. Hanya saja tertulis dalam point 22 bahwa segala macam perselisihan yang timbul diselesaikan sesuai hukum positif di Indonesia dan 
penyelesaian nya di Pengadilan Indonesia (Muhammad, 2020). Hal ini merupakan salah satu kekurangan syarat dan ketentuan PT. IFB Indonesia, seharusnya menambahkan point dalam syarat dan ketentuan untuk menyelesaikan sangketa yang secara musyarah karena di PT. IFB Indonesia selalu mengutamakan untuk menyelesaikan masalah dengan cara ,usyawarah. Selain itu upaya penyelesaian di pengadilan merupakan hal yang kurang disukai oleh perusahaan sebab akan banyak konsekuensi yang akan dihadapi oleh perusahaan apabila menyelesaikan permasalahan di pengadilan.

PT. IFB dengan pihak pemilik barang memilih untuk menyelesaikan sangketa non litigasi yang bentuknya adalah negosiasi. Dalam melakukan negosiasi para pihak nya akan melakukan musyawarah untuk menyelesaikan masalahnya. Prosedur dalam negosiasi ini akan diserahkan kepada pihak yang bersangketa dan para pihak bebas untuk memiliki mekanisme nya sendiri dalam melaksanakan negosiasi.

Berikut proses dari penyelesaian masalah yang dilakukan oleh PT. IFB Indonesia dalam menyelesaikan permasalahannya sesuai dengan hasil dari wawancara dengan perwakilan PT. IFB Indonesia:

a. Saat pihak penerima barang mengetahui bahwa adanya kerusakan dalam salah satu barang muatan yaitu spare part dari keramik, pihak penerima barang menghubungi PT. IFB Indonesia.

b. PT. IFB Indonesia mengarahkan pihak penerima barang untuk menyertakan beberapa dokumen seperti foto barang beserta details kondisinya, foto pada saat unloading barang muatan dari trucking, berita acara dari gudang pada saat barang diterima dari trucking, dan surat jalan/receipt dari pihak gudang Surabaya ke pihak trucking.

c. Selanjutnya penerima barang menyertakan beberapa dokumen yang telah diminta oleh PT. IFB Indonesia untuk kepentingan klaim. Didalam klaim yang ditujukan kepada pihak PT. IFB Indonesia, pihak penerima barang meminta ganti kerugian sebesar 440 EUR.

d. PT. IFB Indonesia tidak dapat memenuhi permintaan klaim yang diminta oleh pihak penerima. Dan PT. IFB Indonesia memberikan sebesar 150 USD sesuai dengan kesepakatan Perusahaan PT. IFB Indonesia.

Pasal 473 KUHD menjelaskan bahwa "apabila adanya kerusakan, maka pengangkut harus mengganti dengan jumlah uang yang diperolehnya lalu dikurangi dengan harga barang yang rusak, dan dikurangi dengan biaya pengangkutan". Menurut pasal ini pihak pengangkut yaitu PT. IFB Indonesia harusnya memberikan ganti kerugian sesuai dengan harga barang muatan yang rusak, seperti paada saat barang muatan itu diserahkan dengan dikurangi biaya pengangkutan beserta bea.

Pemberian ganti kerugian yang diberikan oleh PT. IFB Indonesia terlihat seperti adanya kejanggalan dengan pemberian ganti kerugian yang diberikan oleh PT. IFB Indonesia yang belum sesuai dengan syarat dan ketentuan PT. IFB 
Indonesia maupun KUHD. Menurut wawancara dengan perwakilan PT. IFB Indonesia alasan memberikan ganti keugian dengan jumlah 150 USD adalah berdasarkan kesepakatan dari pimpinan PT. IFB Indonesia.

Klaim harus diberitahukan kepada PT. IFB Indonesia dalam waktu maksimal 14 hari terhitung dari pemilik menerima barang muatan. Klaim juga harus dilakukan secara tertulis pada PT. IFB Indonesia. Sesuai dengan syarat dan ketentuan pasal 19.

Selanjutnya setelah penyelesaian masalah diselesaikan oleh PT. IFB Indonesia dan pemilik barang maka PT. IFB Indonesia akan melanjutkan permasalahan ini kepada pihak pelayaran karena pihak pelayaran adalah pihak yang bekerjasama dengan PT. IFB Indonesia untuk mengangkut barang muatan.

\section{Kesimpulan}

Wanprestasi yang dilakukan oleh PT. IFB Indonesia dengan pemilik barang yang berupa "melakukan prestasi tapi tidak sempurna" karena barang sampai kepada penerima terdapat kerusakan. Sehingga PT. IFB Indonesia harus menerima akibat dari wanprestasi tersebut yaitu perjanjian antara para pihaknya batal dan PT. IFB Indonesia diharuskan untuk membayar ganti kerugian kepada pihak pemilik barang.

Permasalahan diselesaikan oleh PT. IFB Indonesia dengan melalui jalur non litigasi yaitu negosiasi antara para pihaknya. PT. IFB Indonesia memberikan ganti kerugian yang kurang sesuai dengan KUHD maupun di perjanjian karena menurut wawancara dari perwakilan PT. IFB Indonesia uang ganti kerugian yang diberikan sesuai dengan kesepakatan PT. IFB Indonesia. 


\section{BIBLIOGRAFI}

Ali, Z. (2016). Metode penelitian hukum. Jakarta: Sinar Grafika. Google Scholar.

Farida, R., \& Witasari, A. (2020). Tinjauan Hukum Terhadap Penggunaan Letter of Indemnity Tanpa Penyerahan Bill of Lading atau Konosemen Dalam Pengangkutan Laut. Prosiding Konferensi Ilmiah Mahasiswa Unissula (KIMU) Klaster Hukum.Google Scholar

Fathony, M. (2017). Implikasi hukum pembuatan akta pemindahan hak atas hak milik atau hak guna bangunan untuk rumah susun bagi warga negara asing. UNS (Sebelas Maret University).Google Scholar

Hernoko, A. Y. (2010). Hukum perjanjian asas proporsionalitas dalam kontrak komersial. Kencana.Google Scholar

Muhammad, A. (2020). Tanggung Jawab Hukum Pt Mrt Jakarta Terhadap Penumpang Ketika Terjadi Gangguan Listrik Padam Dalam Perjalanan.Google Scholar

Pertiwi, B. R. (2019). Tinjauan Yuridis Pengangkutan Barang Melaui Laut Dalam Bill Of Lading. Universitas Ahmad Dahlan.Google Scholar

Rahmayani, N. (2018). Tinjauan Hukum Perlindungan Konsumen Terkait Pengawasan Perusahaan Berbasis Financial Technology di Indonesia. Pagaruyuang Law Journal, 2(1), 24-41.Google Scholar

Sapa, M. I. (2017). Studi Analisis terhadap Putusan Pengadilan Tata Usaha Negara tentang Sengketa Kepegawaian Nomor. 47/G/2015/PTUN. Mks (Suatu Tinjauan atas Siyasah Syar'iah). Universitas Islam Negeri Alauddin Makassar.Google Scholar

Saraswati, A., Baihaqi, I., \& Anggrahini, D. (2017). Membangun Supply Chain Resilience dengan Pendekatan Quality Function Development: Studi Kasus Perusahaan Freight Forwarder. Jurnal Sains Dan Seni ITS, 6(2), D271D275.Google Scholar

Sinaga, N. A. (2018). Peranan Asas-Asas Hukum Perjanjian Dalam Mewujudkan Tujuan Perjanjian. Binamulia Hukum, 7(2), 107-120.Google Scholar

Tjitrawati, A. T. (2010). Penataan Aturan Hipotik Kapal Setelah Berlakunya UndangUndang Nomor 17 Tahun 2008 Tentang Pelayaran. Yuridika, 25(3), 286303. Google Scholar

Turagan, A. F. (2019). Pelaksanaan Perjanjian Dengan Itikad Baik Menurut Pasal 1338 Kuhperdata. Lex Privatum, 7(1)Google Scholar.

Wicaksono, D. B. (2017). Perlindungan Hukum Terhadap Konsumen Go-Jek (Layanan Transportasi Dengan Aplikasi Online) Dalam Perjanjian Aplikasi Go-Jek 
Wanprestasi Perusahaan Freight Forwarder dalam Pengiriman Barang Muatan Melalui Laut

Berdasarkan Pasal 1320 KUHPerdata. Justitia Jurnal Hukum, 1(2).Google Scholar

Ridwan Khairandy, et al., Pengantar Hukum Dagang Indonesia I, Gama Media, Yogyakarta, 2011.Google Scholar

Ridwan Khairandy, Pokok-pokok Hukum Dagang di Indonesia, Yogyakarta, FH UII Press, 2013.Google Scholar

Zainal Asikin, Hukum Dagang, RajaGrafindo Persada, Jakarta, 2013.Google Scholar

Zulham, Hukum Perlindungan Konsumen, Kencana, Jakarta, 2013 Google Scholar

\section{Copyright holder:}

Elvira Fitria Octavia (2021)

First publication right:

Jurnal Syntax Admiration

This article is licensed under:

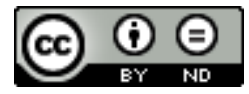

